\title{
STRATEGI PENGEMBANGAN \\ DESA WISATA CATUR, KINTAMANI-BANGLI \\ PADA MASA PANDEMI COVID-19
}

\author{
Anak Agung Dewi Swariwyanyani \\ Universitas Udayana \\ Email: dewiswari74@gmail.com
}

Syamsul Alam Paturusi

Universitas Udayana

Email: syamsul_alam_paturusi@yahoo.fr

\author{
Widiastuti \\ Universitas Udayana \\ Email: wiwiedwidiastuti@yahoo.fr
}

\begin{abstract}
Bali is known as one of the best tourist destination islands in the world. Catur Village is one of the Balinese village which is designated as a Tourism Village by the Bangli Regency Government. Along with the government's efforts to promote tourism development, the Covid-19 Pandemic suddenly occurred. The tourism development program is not implementing as planned. This research will be carried out with a qualitative approach and SWOT-Interpretive analysis. The period before the Covid19 pandemic was marked by the most visited natural attractions are citrus and coffee plantations, and also the acculturation of Balinese and Chinese cultures. The changing conditions of tourism activities during the Covid-19 pandemic in the Catur Tourism Village can be seen from the change in behavior in dealing with the New Normal Life. The life adaptation in the form of implementing the Health Protocol in a good and disciplined manner. The innovation and collaboration are conducted to produce herbal products. In the Pandemic of Covid-19, the Management Strategy in the Development of the Catur Tourism Village was carried out on the main platform "Innovation, Adaptation and Collaboration". Tourism segmentation in the future will be more to personalize, customize, localize, and smaller in size.
\end{abstract}

Keywords: Development Strategy, Tourism Village, Covid-19 Pandemic, Catur Village. 


\section{Pendahuluan}

Pada masa wabah Covid-19 ini terjadi, banyak ahli berpendapat bahwa pembangunan di Bali tidak seharusnya hanya bertumpu pada sektor kepariwisataan, tetapi pembangunan sektor kepariwisataan semestinya dipadukan dengan sektor pertanian. Berpijak dari ide atau gagasan untuk mengkolaborasikan antara kedua sektor tersebut, maka salah satu cara adalah dengan mengembangkan Desa Wisata masa pandemi Covid-19. Pulau Bali sebagai salah satu destinasi pariwisata ternama memiliki banyak desa yang telah dikembangkan sebagai Desa Wisata, akan tetapi hanya beberapa yang berkembang dengan baik dan selainnya tidak berkembang. Berbagai konsep pengembangan Desa Wisata telah diimplementasikan seperti konsep budaya, konsep kerakyatan, konsep hijau, dan konsep berkelanjutan.

Desa Catur adalah salah satu desa yang terletak di Kecamatan Kintamani, Kabupaten Bangli, dikenal sebagai salah satu penghasil kopi Kintamani. Disamping itu memiliki berbagai atraksi alam dan atraksi budaya yang dalam beberapa tahun terakhir dikunjungi wisatawan. Desa Catur terletak di segitiga strategis "3B" yang menghubungkan tiga kabupaten, yaitu Bangli, Badung dan Buleleng. Desa Catur telah ditetapkan sebagai Desa Wisata pada "Masa Sebelum Pandemi Covid- 19" oleh Pemerintah Kabupaten Bangli melalui Peraturan Bupati Bangli Nomor: 4 Tahun 2018. Desa Wisata Catur juga telah mendapatkan juara atau award dalam Lomba Desa Wisata tingkat Provinsi Bali yang dituangkan dalam SK. Gubernur Bali Nomor: 1726/03-Q/HK/2019.

Desa Wisata Catur terletak di dataran tinggi yang berhawa sejuk dengan sebaran atraksi alam seperti air terjun, mata air, sungai, pegunungan, dan beribu hektar hamparan ladang kopi serta jeruk yang berpotensi menjadi atraksi alam buatan. Selain atraksi alam, di Desa Wisata Catur juga dijumpai adanya atraksi budaya unik berupa akulturasi budaya Bali dan Tionghoa yang terlihat pada beberapa pelinggih atau bangunan pemujaan di Pura Penyagjagan. Pada permukiman 
penduduk keturunan Tionghoa juga dapat ditemukan bangunan pemujaan berupa konco disamping rumah tempat tinggal dengan elemen-elemen khas arsitektur China. Jika dilihat dari potensi pariwisata dimana keberadaan akulturasi budaya BaliTionghoa dan potensi alam berupa perkebunan kopi terindikasi geografis dapat dijadikan keunggulan komparatif dalam pengembangan Desa Wisata Catur.

Fasilitas umum untuk menunjang pengembangan Desa Wisata Catur berupa bangunan Badan Usaha Milik Desa (BUMDES) yang juga difungsikan untuk memajang hasil inovasi dan kerajinan masyarakat, ruang Kelompok Sadar Wisata (PokDarWis), ruang operasional untuk Badan Penglola Desa Wisata Catur. Ada beberapa fasilitas publik yang telah terbangun, seperti: pasar, bank, puskesmas, warung, toko, dan lain-lain. Fasilitas pariwisata berupa rumah makan dan villa untuk penginapan, akan tetapi jumlah villa ini masih terbatas. Fasilitas umum dan pariwisata di Desa Wisata Catur pada umumnya dibangun secara parsial. Potensi wisata yang dimiliki Desa Wisata Catur belum dikembangkan dan dikelola secara baik serta optimal. Partisipasi masyarakat masih bersifat pasif, hal ini menjadi kurang optimalnya pengembangan Desa Wisata Catur.

Potret potensi DTW atraksi alam dan budaya di Desa Wisata Catur pada Masa Pandemi Covid- 19 tidaklah jauh berbeda dengan Masa Sebelum Pandemi. Perbedaan jelas terlihat pada tatanan kehidupan yang harus berdaptasi dengan norma baru. Protokol kesehatan standar sebagai norma baru pada Masa Pandemi Covid-19 dengan cara selalu menggunakan masker, sabun untuk mencuci, mengatur jarak, serta tidak berkerumun. Beberapa DTW dan fasilitas pariwisata di Desa Wisata Catur telah melaksanakan standar Prokes, seperti tersedianya sarana wastafel cuci tangan dan sabun, cek suhu tubuh, serta pengaturan jarak tempat duduk.

Selain kegiatan penataan fisik di Masa Pandemi Covid-19, Desa Wisata Catur juga melakukan berbagai kegiatan yang sifatnya non fisik. Kegiatan tersebut berupa usaha untuk meningkatkaan kesadaran masyarakat tentang pentingnya penerapan 
standar Protokol Kesehatan. Upaya pemberdayaan masyarakat dilakukan melalui rintisan industri skala kecil dengan mengolah tanaman herbal yang dihasilkan dari Kebun Induk Kelompok Wanita Tani (KWT) ataupun rumah- rumah anggota KWT dan perumahan warga. Inovasi produk herbal merupakan salah satu langkah adaptasi memasuki Tatanan Kehidupan Normal Baru, selain dapat menjadi produk kenangan sekembali berwisata dari Desa Wisata Catur.

Pengembangan Desa Wisata Catur belum didasarkan pada strategi yang bersifat menyeluruh dan terintegrasi. Pengembangannya masih bersifat sederhana, spontan dan mengikuti arus, terlihat dari belum adanya pemandu lokal atau guide yang mengarahkan wisatawan untuk mengeksplorasi kawasan desa dengan berbagai potensi atraksinya. Tourism Information Center (TIC) sebagai tempat untuk pengurusan tiket masuk Desa Wisata belum berfungsi dan kurangnya papan informasi atau signage sebagai tanda untuk wisatawan. Pokdarwis belum bekerja secara optimal karena kurangnya sumber daya manusia dan tenaga kerja masih minim untuk melaksanakan kewajibannya sesuai dengan jobdesk serta kurangnya fasilitas yang mendukung pekerjaannya. Pengarahan berupa promosi belum dikelola secara baik dan profesional, belum ada service management menyebabkan wisatawan menikmati Desa Wisata Catur secara self services. Pengawasan dalam pengembangan Desa Wisata Catur belum ada sehingga semua berjalan dengan sendirinya tanpa Controlling.

Strategi pembangunan dan pengembangan Desa Wisata Catur diperlukan untuk memberikan manfaat secara ekologi, sosial budaya dan ekonomi, terutama tentang strategi pengelolaan Desa Wisata Catur pada Masa Pandemi Covid-19. Strategi pengelolaan yang akan dirumuskan harus memperhatikan kekuatan dan kelemahan serta mempertimbangkan peluang dan ancaman. Masukan dan pendapat dari elemen penthahelix pariwisata diperlukan dalam pengembangannya. Berdasarkan paparan fenomena faktual tersebut diatas, maka penelitian mengenai “Strategi Pengembangan Desa Wisata Catur, Kintamani-Bangli Pada Masa Pandemi Covid-19" penting untuk dilakukan. 


\section{Teori dan Metode}

Penelitian yang berjudul "Strategi Pengembangan Desa Wisata Catur, Kintamani-Bangli Pada Masa Pandemi Covid-19" ini akan mempergunakan beberapa teori untuk membedah berbagai permasalahan terkait Disaster/Kebencanaan, Pembangunan Destinasi Kepariwisataan, Protokol Kesehatan, CHSE (Cleanlines, Health, Safety and Environment Sustainability), Green Zone, dan DMO (Destination Management Organization).

Teori Disaster / Kebencanaan dapat didefinisikan dalam berbagai arti baik secara normatif menurut peraturan perundang-undangan maupun dari kajian akademik menurut pendapat ahli. Berdasarkan jenis-jenis bencana Pandemi Corona Virus Disease 2019 (Covid-19) yang sedang mewabah di seluruh dunia saat ini digolongkan ke dalam "Bencana Nonalam". Tahap awal pemerintah melakukan tanggap darurat dan bantuan darurat, salah satu bukti tanggap darurat pemerintah adalah disediakannya berbagai test kesehatan yang dilakukan pada setiap gate-gate atau pada setiap batas wilayah, bantuan darurat yang disediakan pemerintah bisa melalui bantuan langsung tunai pada setiap desa, sehingga nantinya pemulihan, rehabilitasi dan rekonstruksi tatanan sosial dapat segera bisa diwujudkan.

Teori Pembangunan Destinasi Kepariwisataan, pariwisata dapat dikatakan sebagai industri tanpa cerobong asap yang mampu menciptakan pertumbuhan ekonomi melalui pembukaan kesempatan kerja serta mengaktifkan sektor produksi lainnya. Pembangunan pariwisata didasarkan pada keaslian alam serta keunikan budaya yang ada dalam suatu masyarakat, hal inilah yang menjadi dasar dalam pengembangan dan pengelolaan pariwisata.

Standar Protokol Kesehatan, dalam kondisi Pandemi Covid-19 masyarakat memiliki peran penting dalam memutus mata rantai penularan Covid-19 agar tidak menimbulkan sumber kluster baru penularan baru Covid-19 pada tempat dimana adanya pergerakan orang, tempat interaksi antar manusia dan berkumpulnya orang. 
Masyarakat dapat beraktivitas kembali dalam situasi Pandemi Covid-19 dengan menerapkan Protokol Kesehatan (Prokes) dan beradaptasi dengan Tatanan Kehidupan Normal Baru. Penerapan Prokes yang ketat dimaksudkan untuk meningkatkan dapat kepercayaan wisatawan terhadap obyek wisata, dan dapat memberikan rasa aman dan nyaman.

Standard an Sertifikasi CHSE (Cleanlines, Health, Safety and Environment Sustainability), hal ini termuat dalam Peraturan Menteri Pariwisata dan Ekonomi Kreatif/Kepala Badan Pariwisata dan Ekonomi Kreatif Republik Indonesia Nomor 13 Tahun 2020. Penerbitan Peraturan Menteri ini untuk menumbuhkan kepercayaan wisatawan baik nusantara maupun mancanegara untuk berwisata dengan aman, nyaman, dan sehat. Sertifikasi CHSE salah satunya dapat diberikan kepada Destinasi Pariwisata, dalam hal ini berupa Desa Wisata, Desa Adat, atau Kampung Wisata. Standar yang dinilai terdiri dari : dimensi, kriteria, dan indikator. Penilaian untuk standar Dimensi mencakup kebersihan, kesehatan, keselamatan kerja, dan kelestarian lingkungan. Penilaian Kriteria meliputi : manajemen/tata kelola, kesiapan Sumber Daya Manusia, dan partisipasi pengunjung, tamu, pengguna, dan pihak lain.

Zona Hijau atau Green Zone yang dimaksud adalah bagaimana mengimplementasikan agar orang yang masuk dan beraktifitas di kawasan sudah tervaksin. Jika mereka belum divaksin, maka yang bersangkutan wajib melakukan swab antigen di lokasi sebagai skrining. Dalam artian orang yang beraktifitas di kawasan menjadi terfilter, dengan tetap menjaga implementasi Protokol Kesehatan dengan ketat, melakukan tracing dan testing, adapun syarat wajib Green Zone atau Zona Hijau menurut Surat Edaran Pemerintah Provinsi Bali. Konsep Green Zone ini diciptakan sebagai upaya perlindungan baik luar maupun dalam bagi wilayah atau Daya Tarik Wisata terhadap penyakit atau hal yang tidak diinginkan pada masa selanjutnya. 
DMO (Destination Management Organization) atau Tata Kelola Destinasi Pariwisata adalah sebuah sistem yang memfasilitasi organisasi pariwisata untuk menciptakan destinasi pariwisata yang berkualitas, berdaya saing dan berkelanjutan. Tata Kelola Destinasi Pariwisata dihasilkan melalui suatu proses dalam bentuk kolaborasi, kerjasama, serta kepemimpinan untuk mewujudkan kesepakatan. Ada banyak cara kerjasama yang dapat meningkatkan daya saing dan inovasi pada sebuah destinasi pariwisata. Untuk mengoptimalkan daya tarik, aksesbilitas, fasilitas, dan masyarakat diperlukan implementasi yang konsisten dan pengendalian yang cermat.

Penelitian ini mempergunakan pendekatan kualitatif dan analisis SWOT untuk menganalisis kondisi pariwisata Desa Wisata Catur Sebelum dan Pada Masa Pandemi Covid-19. Kemudian pendekatan kualitatif dengan analisis interpretatif untuk menemukan kegiatan pariwisata yang berubah pada Masa Pandemi Covid-19. Analisis SWOT-interpretatif digunakan untuk merumuskan strategi pengelolaan dalam pengembangan Desa Wisata pada Masa Pandemi Covid-19. Berdasarkan hasil pengumpulan dan klasifikasi data selanjutnya dilakukan Analisis SWOT menggunakan matriks IFE dan EFE. Hasil dari analisis faktor internal dan eksternal tersebut diinterpretasikan untuk menentukan strategi pengelolaan yang dapat diterapkan dalam Pengembangan Desa Wisata Masa Pandemi Covid-19 di Desa Catur. Dalam penelitian ini, penentuan informan dengan cara purposive sampling. Informan adalah mereka yang memahami Desa Wisata Catur dan permasalahan penelitian. Informan mewakili elemen Pentahelix yaitu Academician, Business, Community, Government, and Media.

\section{Gambaran Umum Desa Catur}

Desa Catur termasuk dalam wilayah Kecamatan Kintamani, Kabupaten Bangli, Provinsi Bali, tepatnya berada di ujung Barat Laut wilayah Kecamatan Kintamani dengan luas wilayah sekitar 7,56 km2 dan terletak pada ketinggian $1.100 \mathrm{~m}$. sampai dengan 1.250 m. di atas permukaan laut. Letak Desa Catur sangat strategis karena 
dilalui oleh jalan provinsi, berjarak sekitar 15 km. dari Kota Kecamatan, 36 km. dari Kota Bangli, dan dari Kota Denpasar jaraknya 60 km. serta dapat ditempuh dalam waktu 90 menit.

Jumlah penduduk di Desa Catur selalu berubah setiap tahunnya, berdasarkan data monografi Desa Catur tahun 2020, berjumlah 452 KK. terdiri dari penduduk lakilaki sebanyak 1.039 jiwa dan jumlah penduduk perempuan 976 jiwa. Berdasarkan mata pencahariannya, sebagian besar masyarakat Desa Wisata Catur atau sebanyak 997 jiwa masih bekerja di sektor pertanian. Walaupun ada yang bekerja di luar sektor pertanian, namun tidak sedikit yang bekerja di dua sektor bahkan lebih. Berdasarkan data dari monografi Desa Catur tahun 2020, kegiatan ekonomi di Desa Catur bidang pertanian sebagian besar ditanami kopi seluas 470 hektar, jeruk 304 hektar, dan sayuran sekitar 20 hektar.

Lahan perkebunan di Desa Wisata Catur dikelola oleh delapan kelompok subak yang tersebar di setiap banjar. Aneka produk perkebunan tumbuh dengan baik dikarenakan kondisi tanah yang subur dan iklim yang sejuk. Adapun hasil unggulan yang terkenal di Desa Wisata Catur berupa kopi arabika sebagai produk Kopi Kintamani yang telah mendapat pengakuan sebagai kopi terindikasi geografis (IG). Peredaran produk "Kopi Kintamani" telah dilakukan ke seluruh kabupaten kota seBali, daerah lain di Indonesia, dan bahkan sampai mancanegara, seperti: Benua Asia, Eropa, Amerika, dan Australia. Selain kopi, terdapat juga budidaya tanaman perkebuanan lainnya, seperti: jeruk, terong Belanda, dan beraneka sayur mayur. 


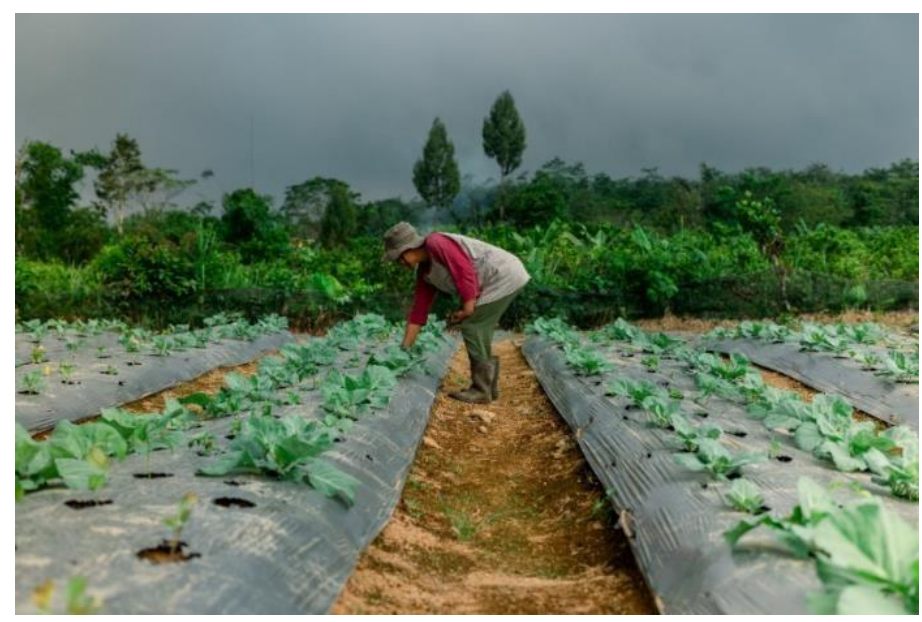

Gambar 1. Aktivitas Di Perkebunan Sayur Desa Catur

\section{Pengembangan Pariwisata Sebelum dan Masa Pandemi Covid-19 di Desa Wisata Catur, Kintamani-Bangli}

Pemerintah Kabupaten Bangli melalui Peraturan Bupati Bangli Nomor: 4 Tahun 2018 telah menetapkan Desa Catur sebagai Desa Wisata bersama dengan 28 (duapuluh delapan) Desa Wisata lainnya yang tersebar di 4 (empat) kecamatan, yaitu: Kecamatan Kintamani, Kecamatan Bangli, Kecamatan Tembuku, dan Kecamatan Susut. Penetapan Desa Catur sebagai Desa Wisata tentunya telah mempertimbangkan dan mengkaji berbagai potensi wisata, baik tergolong dalam atraksi alam, atraksi budaya maupun atraksi buatan. Penetapan ini dikeluarkan pada masa sebelum Pandemi Covid-19 di Desa Catur, ketika pariwisata hidup normal, cepat, dan dinamis.

Terdapat 4 tujuan yang hendak dicapai/didapatkan oleh wisatawan, yaitu: 1) something to see dimana suatu daerah tujuan wisata memiliki daya tarik khusus disamping atraksi wisata yang menjadi interest-nya; 2) something to do dimana pada suatu daerah tujuan wisata perlu memiliki atraksi wisata yang dapat dilakukan oleh wisatawan; 3) something to buy dimana sebuah daya tarik wisata harus memiliki fasilitas untuk berbelanja seperti souvenir atau oleh-oleh yang dapat dibeli oleh wisatawan; 4) something to know dimana suatu daya tarik wisata dapat memberikan nilai edukasi bagi wisatawan. 
Melihat hal tersebut, untuk Pengembangan Desa Wisata Masa Pandemi Covid19 di Desa Catur tentunya tidak bisa terlepas dari komponen destinasi pariwisata $4 \mathrm{~A}$ (attraction, accessibility, amenities, dan ancillary service) yang diuraikan sebagai berikut:

a) Atraksi (attraction), Terdapat beberapa daya tarik wisata yang berada di Desa Catur yang dibedakan menjadi dua, yaitu: atraksi alam dan atraksi budaya. Atraksi alam berupa panorama perkebunan kopi, jeruk, bunga gumitir, air terjun Tiying Seni, dan air terjun Langse. Atraksi budaya seperti akulturasi antara budaya Bali dengan Tionghoa, perayaan imlek bersama di Pura Penyajagan dan diikuti pagelaran Barongsai.

b) Aksesibilitas (accessibility), Desa Wisata Catur dilalui oleh jalan Provinsi, Kabupaten, Kecamatan yang telah di hotmix, serta jalan lingkungan, dan jalan ke DTW yang kondisinya masih tanah dan berbatu.

c) Fasilitas penunjang pariwisata (amenities), Salah satu fasilitas penunjang pariwisata di Desa Wisata Catur ini adalah sebuah gedung TIC (Tourism Information Center) dan juga difungsikan sebagai kantor badan pengelola Desa Wisata Catur.

d) Kelembagaan (ancillary), Di Desa Wisata Catur terdapat salah satu kelembagaan yaitu Badan Usaha Milik Desa yang bernama Catur Mulia Santhi.

Untuk mengetahui seberapa besar perkembangan potensi pariwisata sebelum Pandemi Covid- 19, berdasarkan hasil wawancara dan observasi yang di lakukan oleh peneliti, maka di peroleh hasil bahwa SWOT (Strength, Weakness, Opportunity, Threats) Pengembangan Desa Wisata Catur tertera pada Tabel 1 di bawah ini. 
Tabel 1. Matrik SWOT Strategi Pengembangan Desa Wisata Catur, Kintamani-Bangli Pada Masa Pandemi Covid-19

\begin{tabular}{|c|c|c|}
\hline Faktor Eksternal & $\begin{array}{l}\quad \text { Kekuatan (Strengths, S) } \\
\text { 1. Adanya akulturasi budaya Bali } \\
\text { dengan Tionghoa } \\
\text { 2. Mempunyai ikatan } \\
\text { kekerabatan Baliaga-Konsep } \\
\text { Hulu-Apad } \\
\text { 3. Memiliki warisan budaya } \\
\text { berupa tinggalan artefak Masa } \\
\text { Bali Kuno } \\
\text { 4. Memiliki pengakuan terhadap } \\
\text { produk bio diversity Kopi } \\
\text { Kintamani Indikasi Geografis (IG) } \\
\text { 5. Telah mendapatkan award dalam } \\
\text { Lomba Desa Wisata tingkat } \\
\text { Provinsi Bali }\end{array}$ & $\begin{array}{l}\text { Kelemahan (Weaknesses, } \mathrm{W} \text { ) } \\
\text { 1. Kurangnya pemahaman } \\
\text { masyarakat tentang arti } \\
\text { penting warisan budaya dan } \\
\text { alam } \\
\text { 2. Terbatasnya pemahaman } \\
\text { Sumber Daya Manusia } \\
\text { tentang pariwisata/ } \\
\text { hospitality } \\
\text { 3. Kurangnya tata bangunan } \\
\text { dan tata lingkungan di Desa } \\
\text { Catur } \\
\text { 4. Kebersihan masih kurang } \\
\text { 5. Terbatasnya pemanfaatan } \\
\text { media informasi }\end{array}$ \\
\hline $\begin{array}{l}\text { Peluang (Opportunities, O) } \\
\text { 1. } \begin{array}{l}\text { Pergeseran trend } \\
\text { kepariwisataan global } \\
\text { dari wisata massal (mass } \\
\text { tourism) ke wisata } \\
\text { berkualitas (quality } \\
\text { tourism) }\end{array} \\
\text { 2. Suasana pedesaan yang } \\
\text { alami dan sebagian } \\
\text { besar dimanfaatkan } \\
\text { sebagai lahan } \\
\text { perkebunan } \\
\text { 3. Pandemi Covid-19 } \\
\text { menuntut manusia } \\
\text { untuk menghindari } \\
\text { kerumunan } \\
\text { 4. Sebelum Covid-19, telah } \\
\text { melakukan rintisan } \\
\text { inovasi dan kolaborasi } \\
\text { 5. Pengembangan } \\
\text { produk UMKM } \\
\text { berbasis herbal }\end{array}$ & 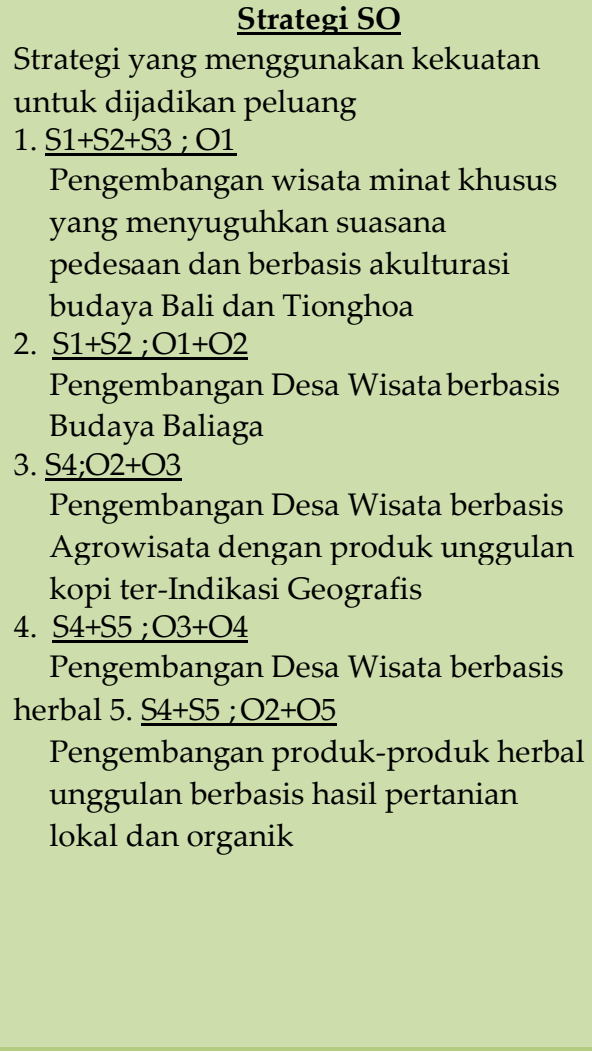 & 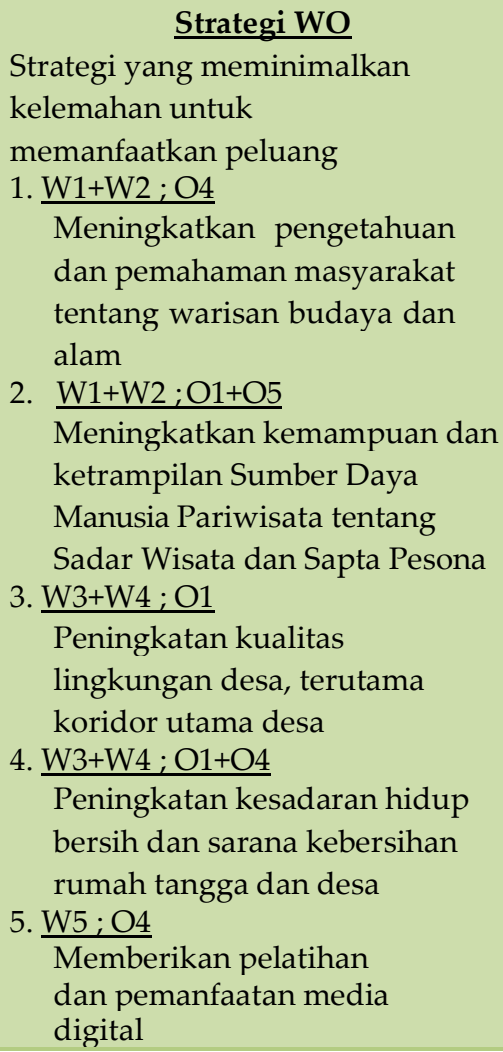 \\
\hline
\end{tabular}




\begin{tabular}{|c|c|c|}
\hline $\begin{array}{l}\text { Ancaman (Threats, T) } \\
\text { Munculnya destinasi } \\
\text { wisata baru } \\
\text { 2. Pembangunan Desa } \\
\text { Wisata jika tidak } \\
\text { dikontrol dan } \\
\text { dikendalikan dengan } \\
\text { baik akan } \\
\text { mengakibatkan } \\
\text { kerusakan alam dan } \\
\text { hilangnya warisan } \\
\text { budaya } \\
\text { 3. Kedatangan wisatawan } \\
\text { dapat membawa } \\
\text { dampak positif dan } \\
\text { negative } \\
\text { 4. Gangguan kesehatan } \\
\text { dan keamanan } \\
\text { merupakan dampak } \\
\text { utama serta nyata di } \\
\text { masa pandemi }\end{array}$ & $\begin{array}{l}\text { Strategi ST } \\
\text { Strategi yang menggunakan kekuatan } \\
\text { untuk mengatasi ancaman } \\
\text { 1. } \frac{\mathrm{S} 1+\mathrm{S} 3 ; \mathrm{T} 1}{\text { Pengembangan Daya Tarik Wisata }} \\
\text { yang memiliki keunikan } \\
\text { 2. } \frac{\mathrm{S} 1+\mathrm{S} 2+\mathrm{S} 3+\mathrm{S} 4 ; \mathrm{T} 2+\mathrm{T} 3}{\text { Peningkatan upaya konservasi alam }} \\
\text { dan budaya } \\
\text { 3. } \frac{\mathrm{S} 1+\mathrm{S} 2+\mathrm{S} 3+\mathrm{S} 4 ; \mathrm{T} 1+\mathrm{T} 2+\mathrm{T} 3}{\text { Peningkatan kecintaan terhadap alam, }} \\
\text { adat istiadat dan budaya } \\
\text { 4. } \frac{\mathrm{S} 2+\mathrm{S} 5 ; \mathrm{T} 3+\mathrm{T} 4}{\text { Penerapan Protokol Kesehatan secara }} \\
\text { disiplin sehingga termasuk ke dalam } \\
\text { Zona Hijau Desa Wisata }\end{array}$ & $\begin{array}{l}\text { Strategi WT } \\
\text { Strategi yang } \\
\text { meminimalkan kelemahan } \\
\text { untuk menghindari } \\
\text { ancaman } \\
\text { 1. W1+W2;T1 } \\
\text { Peningkatan uapaya pelestarian } \\
\text { dan pemeliharaan warisan } \\
\text { budaya dan alam yang potensi } \\
\text { wisata unggulan } \\
\text { 2. W1+W2;T1+T2 } \\
\text { Peningkatan dan } \\
\text { pengembangan paket wisata } \\
\text { budaya, sejarah, agro serta } \\
\text { Desa Wisata Herbal sebagai } \\
\text { unggulan masa Pandemi dan } \\
\text { kedepannya } \\
\text { 33+W4;T2 } \\
\text { Penyusunan Rencana } \\
\text { Induk Pembangunan } \\
\text { Desa Wisata } \\
\text { 4. W4+W5; T3+T4 } \\
\text { Pengembangan Desa Wisata } \\
\text { Herbal yang tanggap dari krisis } \\
\text { wabah dan bencana }\end{array}$ \\
\hline
\end{tabular}

\section{Kegiatan Pariwisata yang Berubah di Masa Pandemi Covid-19 di Desa Wisata Catur, Kintamani-Bangli}

Berdasarkan analisis interpretatif terhadap pengembangan pariwisata Sebelum Masa Pandemi Covid-19 di Desa Wisata Catur dapat ditetapkan beberapa hal yang perlu ditindaklanjuti di Masa Pandemi Covide-19, terutama kaitannya dengan berubahnya kegiatan pariwisata karena harus menerapkan Protokol Kesehatan (Prokes) secara baik dan disiplin. Masa Pandemi Covid-19, terlihat adanya kondisi paradoksial antara kepariwisataan yang mesti mengundang orang untuk berkunjung ke Desa Wisata di satu sisi dengan menghindari kerumunan dalam jumlah banyak guna mengikuti Prokes di sisi yang lain.

Mengkaji hasil analisis SWOT tersebut diatas, melalui analisis interpretatif dirumuskan upaya-upaya dalam mengatasi ancaman agar menjadi kekuatan di Masa Pandemi Covid-19. Terutama upaya menjadikan Desa Wisata Catur termasuk ke dalam Zona Hijau (Green Zone) Desa Wisata di Provinsi Bali. Hal ini menjadi penting 
karena tanpa label Green Zone, suatu desa tidak akan bisa dikunjungi oleh wisatawan mancanegara ketika border penerbangan internasional dibuka. Beberapa persyaratan suatu desa menjadi Green Zone, yaitu minimal 70\% populasinya telah mendapatkan vaksin dua (2) kali, wisatawan boleh berkunjung ke DTW yang telah memperoleh sertifikat CHSE (Cleanlines, Health, Safety, and Environmental Sustainability), dan mudah di tracing pergerakannya lewat barcode yang discan saat tiba di bandara.

Masa Pandemi Covid-19 yang sedang berlangsung saat ini, dimanfaatkan sebagai waktu untuk membangun Desa Wisata Catur terutama dari aspek "Sapta Pesona" yang terdiri dari tujuh unsur, diantaranya: aman, tertib, bersih, sejuk, indah, nyaman, dan kenangan. Hal ini terlihat dari upaya yang dilakukan oleh Bapak Perbekel Desa Catur bersama masyarakatnya melakukan penataan wajah wilayah desa melalui perbaikan, penataan dan pengadaan berbagai fasilitas sarana prasarana, seperti: penataan area parkir desa dan area parkir pura, penataan jalan ke objek-objek wisata termasuk penataan objek wisatanya.

Wilayah Desa Catur sebagian besar difungsikan sebagai perkebunan jeruk dan kopi. Bentuk wisata on farm yang menggabungkan kegiatan wisata dengan pertanian merupakan pilihan terbaik untuk dikembangkan kedepannya. Mata pencaharian masyarakat sebagai petani dan pemahaman yang baik tentang seluk beluk pengetahuan pertanian dapat dipergunakan untuk mendukung wisata on farm. Orang berwisata ke Desa Wisata Catur misalnya di saat musim kopi, wisatawan bisa memetik buah kopi sendiri, mengolah sampai proses menikmati kopi buatan sendiri. Kemudian ketika musim jeruk, wisatawan dapat menikmati cita rasa buah jeruk langsung ketika dipetik dari pohonnya dan memilih buah jeruk yang diinginkan dari pohonnya untuk dibawa pulang sebagai oleh-oleh dari Desa Wisata Catur. 


\section{Strategi Pengelolaan dalam Pengembangan Desa Wisata Masa Pandemi Covid-19 di Desa Wisata Catur, Kintamani-Bangli}

Dewasa ini, pemerintah tetap menggalakkan sektor pariwisata sebagai salah satu lokomotif pendapatan devisa negara meskipun dunia sedang mengalami Pandemi Covid-19. Sektor pariwisata masih tetap menjanjikan karena Masa Covid-19 sekalipun, diperkirakan banyak orang yang akan melakukan perjalanan setelah tidak berpergian selama hampir 1,5 (satu setengah) tahun dari awal sampai dengan saat ini. "Kunci dalam menghadapi megashift (perubahan besar) di sektor pariwisata dan ekonomi kreatif akibat pandemi COVID-19 adalah dengan mengimplementasikan tiga aspek yaitu inovasi, adaptasi, dan kolaborasi" seperti disampaikan oleh Bapak Menteri Sandiaga Salahuddin Uno (Jakarta, 29 Juli 2021).

Pandemi Covid-19 mengharuskan dunia kepariwisataan Indonesia dilaksanakan dalam platform utama untuk "Inovasi, Adaptasi dan Kolaborasi". "Inovasi" dilaksanakan dengan pendekatan big data untuk memetakan potensi dan menguatkan berbagai aspek pada sektor kepariwisataan. Sektor tersebut meliputi target segementasi pasar, paket wisata, produk wisata, atraksi, aksesibilitas, amenitas, dan aktivitas. "Adaptasi" dilakukan melalui cara membiasakan dan mendisiplinkan pemberlakuan protokol CHSE di setiap destinasi wisata. "Kolaborasi" dilakukan dengan semua stakeholders untuk menciptakan lapangan kerja, khususnya subsektor ekonomi kreatif, seperti: kuliner, fesyen, dan kriya. Segmentasi pariwisata ke depan akan lebih bertumpu pada personalize (lebih memilih jenis pariwisata pribadi), customize (lebih memilih wisata minat khusus), localize (lebih memilih destinasi yang jaraknya dekat), dan smaller in size (lebih memilih destinasi wisata yang tidak terlalu besar).

Kesepakatan dalam pengelolaan Desa Wisata Catur juga sejalan dengan platform Kementerian Pariwisata dan Ekonomi Kreatif tentang kolaborasi. Kerjasama atau kolaborasi diantara pemimpin, jajarannya dan masyarakatnya, dalam hal ini 
antara Kepala Desa Dinas Catur dan Jero Bendesa Adat Catur akan sangat tepat dalam pengelolaan karena dengan mempertimbangkan anggota masyarakat kedua bentuk desa itu sama. Pembagian ruang lingkup kerja diantara kedua bentuk desa merupakan langkah terbaik karena fungsinya yang berbeda, Desa Dinas berfungsi untuk melaksanakan fungsi dalam hubungan struktural dengan pemerintah yang lebih tinggi, seperti Pemerintah Kecamatan, Pemerintah Kabupaten, Pemerintah Provinsi, dan bahkan dengan pemerintah Pusat. Desa Adat berfungsi dalam implementasi atau pelaksanaan program Desa Wisata, hal ini didasarkan karakteristik masyarakatnya yang sebagian besar merupakan anggota Desa Adat dan bermatapencaharian sebagai petani, disamping itu masyarakatnya sangat tunduk pada aturan adat dibanding aturan lainnya.

Selain kolaborasi diantara Desa Dinas dan Desa Adat, hal lain yang perlu mendapat perhatian adalah fokus pengembangan DTW dengan atraksi alam maupun budayanya. Desa Wisata Catur merupakan Desa Wisata Rintisan, akan lebih efektif diawali dengan pengembangan atraksi alam berupa perkebunan kopi dan jeruk yang terkait langsung dengan profesi atau aktivitas masyarakatnya sebagai petani. Keseharian warganya sebagai petani menjadikan pemahaman mereka tentang pertanian lebih baik dibandingkan pariwisata, oleh karenanya pengembangan DTW rintisan sebaiknya mengkombinasikan antara pertanian dan pariwisata. Jika integrasi antara kedua sektor dapat dilakukan maka tingkat partisipasi warga masyarakat di garda depan pembangunan Desa Wisata Catur akan meningkat.

DTW atraksi budaya seperti akulturasi budaya Bali-Tionghoa, berupa perkampungan Pecinan khas Bali dan pegelaran budaya tahunan yang dilaksanakan pada perayaan Imlek atau hari raya lainnya dapat menjadi program awal DTW atraksi buadaya rintisan Desa Wisata Catur. Warisan tradisi yang sudah ada dan dilakoni masyarakatnya serta merupakan atraksi budaya khas/unik yang tidak dimiliki oleh desa lain disekitarnya adalah merupakan modal utama dalam pengembangan Desa Wisata Catur. Pengembangan ini lebih efektif karena merupakan tradisi turun 
menurun yang wajib dilaksanakan warganya. Pengelola Desa Wisata hanya perlu menata kawasan dan arsitektur perkampungan sehingga mempercantik tampilan wajah Desa Wisata Catur.

Lebih lanjut, akan dijelaskan secara rinci beberapa strategi dalam pengelolaan dan pengembangan Desa Wisata Catur Masa Pandemi Covid-19, sebagai berikut:

\section{a. Aspek Destinasi Pariwisata}

Strategi Pengembangan Desa Wisata Catur, Kintamani-Bangli Masa Pandemi COVID-19 pada aspek "Destinasi Pariwisata" yang didasarkan pada "Inovasi" dan "Adaptasi".

1. Strategi pengembangan DTW atraksi alam dan atraksi budaya di Desa Wisata Catur yang mengedepankan personalize (jenis wisata yang segmen pasarnya khusus untuk personal/pribadi atau hanya dalam lingkup keluarga), strategi ini dapat dilakukan dengan rencana :

- Pengembangan DTW atraksi alam berbasis Agrowisata dengan produk unggulan kopi Kintamani ter-Indikasi Geografis (IG) dan kebun jeruk Kintamani, dalam hal ini wisatawan dapat melihat perkebunan kopi dan jeruk, dapat ikut menanam, memetik, mengolah buah sampai siap dihidangkan serta menyiapkan untuk dibawa pulang sebagai oleh-oleh;

- Pengembangan DTW atraksi budaya berbasis tinggalan Budaya Baliaga, hal ini dilakukan dengan melihat warisan budaya Baliaga berupa bangunan dan artefak arkeologi yang ada di Desa Catur.

2. Strategi pengembangan DTW atraksi alam dan atraksi budaya di Desa Wisata Catur yang memenuhi wisata minat khusus atau customize, strategi ini dapat dilakukan dengan rencana :

- Mengembangkan DTW atraksi alam berbasis Herbal, pengembangan produk-produk herbal unggulan berbasis hasil pertanian lokal dan organik. 
UP2K KWT Desa Catur selain mengembangkan Kebun Induk untuk tanaman-tanaman herbal dan setiap anggota KWT- nya melakukan penanaman berbagai macam tanaman herbal di rumah masing-masing;

- Menawarkan DTW atraksi budaya berbasis akulturasi budaya, khususnya budaya Bali dan Tionghoa dalam suasana perkampungan kehidupan seharihari masyarakat di Dusun Lampu dan ritual keagamaan di Pura Penyajagan.

3. Strategi pengembangan Desa Wisata Catur yang terkatagori Green Zone atau Zona Hijau Desa Wisata dengan cara:

- Menerapkan Protokol Kesehatan secara terpadu dan disiplin di DTW, fasilitas pariwisata, fasilitas publik, lingkungan desa, perumahan, dan rumah tangga.

- Memberikan Sertifikat CHSE kepada DTW, homestay dan fasilitas pariwisata.

- Meningkatkan jumlah masyarakat yang tervaksinasi Covid-19, terutama usia rentan serta pelaku wisata.

4. Strategi pengembangan Desa Wisata Catur dengan konsep DMO-DG, strategi ini dapat dilakukan cara:

- Membentuk Satgas Covid-19 di Desa Wisata Catur yang beranggotakan berbagai unsur dalam pemerintahan Desa Dinas dan Desa Adat, tokoh masyarakat, pelaku usaha wisata, tenaga kesehatan, media dan unsur terkait lainnya.

- Membentuk Forum Tata Kelola Desa Wisata Catur. yang beranggotakan berbagai unsur dalam pemerintahan Desa Dinas dan Desa Adat, tokoh masyarakat, pelaku usaha wisata, media dan unsur yang terkait lainnya. 


\section{b. Aspek Industri Pariwisata}

Strategi Pengembangan Desa Wisata Catur, Kintamani-Bangli Masa Pandemi COVID-19 pada aspek "Industri Pariwisata" berbasis "Inovasi”.

1. Strategi pengembangan Desa Wisata Catur berdasar pada daya saing produk pariwisata yang bersifat smaller in size (pariwisata dengan jumlah pengunjung di setiap destinasi wisata yang tidak terlalu masif) dengan cara:

- Mengembangkan industri pariwisata yang sesuai dengan karakteristik wisata setempat dan daya dukungnya.

- Mengembangkan industri pariwisata yang sesuai dengan potensi alam dan budaya yang mungkin hanya untuk segmen pasar tertentu.

2. Strategi pengembangan Desa Wisata Catur yang berbasis pada pengembangan tanggung jawab terhadap lingkungan dengan cara:

- Mengangkat ekonomi kreatif berbasis kearifan lokal.

- Memperkenalkan komunitas kreatif yang peduli pada industri berbasis keberlanjutan lingkungan.

\section{c. Aspek Pemasaran Pariwisata}

Strategi Pengembangan Desa Wisata Catur, Kintamani-Bangli Masa Pandemi COVID-19 pada aspek "Pemasaran Pariwisata" berbasis "Inovasi" dan "Kolaborasi".

1. Strategi pengembangan Desa Wisata Catur berdasar pada pasar wisatawan yang bersifat lokal (localize) dengan cara:

- Meningkatkan kerjasama dengan pemerintah, pelaku pariwisata, asosisasi pariwisata, dan media.

- Meningkatkan promosi melalui pemanfaatan media cetak maupun digital. 
2. Strategi pengembangan Desa Wisata Catur dengan membentuk Tourism Village Branding dengan cara:

- Menggali citra/branding yang bersifat komunikatif dan mewakili keunggulan karakter hamparan alam, budaya dan saujana.

- Membuat logo/simbol branding Desa Wisata Catur yang menggambarkan kekuatan nilai dan konsistensi pesan.

\section{d. Aspek Kelembagaan Pariwisata}

Strategi Pengembangan Desa Wisata Catur, Kintamani-Bangli Masa Pandemi COVID-19 pada aspek "Kelembagaan Pariwisata" berbasis "Kolaborasi".

1. Strategi pengembangan Desa Wisata Catur dengan melakukan penguatan organisasi Desa Wisata dengan cara:

- Membentuk Kelompok Sadar Wisata (PokDarWis).

- Membentuk Badan Pengelola Desa Wisata yang beranggotakan unsurunsur keterwakilan dari Desa Dinas dan Desa Adat.

2. Strategi pengembangan Desa Wisata Catur dengan melakukan penngembangan Sumber Daya Manusia/SDM, dengan cara:

- Meningkatkan kemampuan dan keterampilan Sumber Daya Manusia/SDM Desa Wisata mengenai Sadar Wisata, Sapta Pesona, dan CHSE.

\section{Simpulan dan Saran}

Sebelum Masa Pandemi Covid-19, Pemerintah Kabupaten Bangli telah menetapkan Desa Catur sebagai Desa Wisata melalui Peraturan Bupati Bangli Nomor: 4 Tahun 2018. Penetapan sebagai Desa Wisata tentunya telah mempertimbangkan potensi ditinjau dari empat aspek kepariwisataan, yaitu aspek Destinasi, Industri, 
Pemasaran, dan Kelembagaan. Masa Sebelum Pandemi Covid-19 juga ditandai keberhasilan Desa Wisata Catur sebagai Desa Wisata Terbaik Kedua Tingkat Provinsi Bali. Daya Tarik Wisata (DTW) atraksi alam yang banyak dikunjungi adalah perkebunan jeruk dan perkebunan kopi. Kopi Kintamani telah mendapatkan pengakuan Indikasi Geogrfis (IG). DTW atraksi budaya yang banyak dikunjungi wisatawan Sebelum Pandemi Covid-19 adalah akulturasi budaya Bali dan Tionghoa. Kondisi pariwisata Desa Wisata Catur Pada Masa Pandemi Covid-19 sangat memperihatinkan karena DTW atraksi alam tidak banyak dikunjungi, meskipun hasil perkebunan berupa buah jeruk dan kopi tetap menjadi komoditas perdagangan. Demikian halnya dengan DTW atraksi budaya tidak dilaksanakan karena harus mengikuti peraturan pemerintah terkait Pandemi Covid-19. Upaya cukup menggembirakan bahwa para pihak dari Desa Wisata Catur melakukan langkahlangkah adaptasi. Elemen Desa Wisata Catur menyikapi Masa Pandemi Covid-19 dengan melakukan penataan DTW serta merintis pengolahan hasil tanaman rumahan menjadi produk herbal.

Kondisi kegiatan Pariwisata yang Berubah di Masa Pandemi Covid-19 di Desa Wisata Catur, Kintamani-Bangli, terlihat jelas dari perubahan perilaku dalam menghadapi Tatanan Kehidupan Normal Baru. Adaptasi kehidupan berupa penerapan Protokol Kesehatan (Prokes) secara baik dan disiplin. Kegiatan pariwisata tidak berlangsung normal, dan ini dimanfaatkan oleh masyarakat untuk melakukan inovasi dan berkolaborasi untuk menghasilkan produk industri kecil berbasis herbal yang melibatkan partisipasi aktif warga masyarakat di Desa Wisata Catur.

Strategi Pengelolaan dalam Pengembangan Desa Wisata Catur, KintamaniBangli Pada Masa Pandemi Covid-19, dilaksanakan dalam platform utama "Inovasi, Adaptasi dan Kolaborasi". "Inovasi" dengan pendekatan big data untuk memetakan potensi dan menguatkan berbagai aspek sektor kepariwisataan. Sektor tersebut meliputi segementasi pasar, paket wisata, produk wisata, atraksi, aksesibilitas, amenitas, dan aktivitas. "Adaptasi" dilakukan dengan membiasakan dan 
mendisiplinkan pemberlakuan protokol CHSE di destinasi wisata. "Kolaborasi" diantara stakeholders untuk menciptakan lapangan kerja baru, khususnya subsektor ekonomi kreatif, seperti: kuliner, fesyen, dan kriya. Segmentasi pariwisata ke depan akan lebih bertumpu pada personalize (lebih memilih jenis pariwisata pribadi), customize (lebih memilih wisata minat khusus), localize (lebih memilih destinasi yang jaraknya dekat), dan smaller in size (lebih memilih DTW yang tidak terlalu besar). Selanjutnya, segmentasi pariwisata dikaji dari 4 aspek kepariwisataan, yaitu: aspek destinasi, industri, pemasaran, dan kelembagaan.

Adapun saran yang dapat dikemukakan, yaitu: Pengembangan Desa Wisata Catur lebih diprioritaskan pada DTW atraksi alam perkebunan jeruk dan kopi, karena terkait langsung dengan aktivitas masyarakatnya sebagai petani. Upaya pelestarian DTW atraksi budaya khas berupa akulturasi budaya Bali dan Tionghoa, sehingga dapat dimanfaatkan dan dikembangkan untuk kesejahteraan masyarakat. Meningkatkan kemampuan dan keterampilan Sumber Daya Manusia tentang Sadar Wisata, Sapta Pesona, dan CHSE. Penelitian selanjutnya diarahkan untuk mengkaji permasalahan-permasalahan tersebut diatas.

\section{Daftar Pustaka}

Ahmadi, R. 2014. Metodologi Penelitian Kualitatif. Yogyakarta: Ar-Ruzz Media.

Damanik, J., Frans Teguh. 2013. Manajemen Destinasi Pariwisata-Sebuah Pengantar Ringkas. Yogyakarta: Puspar UGM.

Fandeli, C. 2001. Dasar-Dasar Manajemen Kepariwisataan Alam. Yogyakarta: Liberty Offset. Goeldner, C.R., Brent Ritchie. 2009. Tourism Principles, Practices, Philosophies. New Jersey: John Wiley \& Sons, Inc.

Gunn, C.A. 1994. Tourism Planning-Basics, Concepts, Cases. Washington DC: Taylor \& Francis. Hadinoto K. 1996. Perencanaan Pengembangan Destinasi Pariwisata. Jakarta: UI-Press.

Inskeep, Edward. 1991. Tourism Planning: An Integrated and Sustainable Development Approach. New York: Van Nostrand Reinhold. 
Madiun, I N. 2010. Nusa Dua Model Pengembangan Kawasan Wisata Modern. Denpasar: Universitas Udayana.

Marpaung, H. 2002. Pengetahuan Kepariwisataan. Bandung: Alfabeta.

Moleong, L.J. 2013. Metodologi Penelitian Kualitatif - Edisi Revisi, Bandung: PT. Remaja Rosdakarya

Paturusi, S A. 2008. Perencanaan Kawasan Pariwisata. Denpasar: Univeritas Udayana Press. Pitana, I G., I Ketut Surya Diarta. 2009. Pengantar Ilmu Pariwisata. Yogyakarta: Andi Offset. Sugiyono, 2017. Metode Penelitian Kualitatif. Bandung: Alfabeta.

Sunaryo, B. 2013. Kebijakan Pembangunan Destinasi Pariwisata - Konsep dan Aplikasinya di Indonesia. Yogyakarta: Gava Media.

Suwena, I K., I Gst. Ngr. Widyatmaja. 2010. Pengetahuan Dasar Ilmu Pariwisata. Denpasar: Udayana University Press.

Teguh, F. 2015. Tata Kelola Destinasi Membangun Ekosistem Pariwisata. Yogyakarta: Gadjah Mada University Press.

Wardiyanta, 2006. Metode Penelitian Pariwisata. Yogyakarta: Andi Offset.

Warpani, S.P. \& Indira P. Warpani. 2007. Pariwisata Dalam Tata Ruang Wilayah. Bandung: Penerbit ITB.

\section{Profil Penulis}

Anak Agung Dewi Swariwiyanyani, dilahirkan di Kota Denpasar pada tanggal 8 Nopember 1980. Penulis merupakan mahasiswa Program Studi Magister Pariwisata, Fakultas Pariwisata, Universitas Udayana. Pendidikan sarjana diselesaikan pada Program Sarjana di Program Studi Teknik Sipil, Fakultas Teknik, Universitas Udayana pada tahun 2002 dengan memperoleh gelar ST. (Sarjana Teknik). Saat ini penulis bekerja sebagai pegawai pada Bank Negara Indonesia 1946 Kantor Cabang Kota Denpasar.

Syamsul Alam Paturusi, seorang Guru Besar Tetap Perancangan Kota pada Program Studi Arsitektur, Fakultas Teknik, Universitas Udayana. Pendidikan Sarjana beliau selesaikan di Jurusan Arsitektur, Universitas Hasanuddin, Makassar. Pendidikan Magister di Perencanaan Wilayah dan Kota di Institut Teknologi Bandung 
di Bandung, dan jenjang pendidikan Doktor di Université de Pau et des Pays de l'Adour, Prancis.

Widiastuti, menyelesaikan pendidikan Sarjana pada tahun 1989 di Program Studi Arsitektur, Fakultas Teknik, Universitas Udayana. Kemudian menyelesaikan pendidikan tingkat Magister pada tahun 1997 di Arsitektur ITB. Menyelesaikan pendidikan Doktor pada bidang Regional Planning di Université de Pau et des Pays de l'Adour, Prancis pada bulan September tahun 2002. 